\title{
PELATIHAN KONSELING TRAUMATIK BERBASIS EXPERIENTIAL LEARNING PADA KONSELOR
}

\author{
Agus Tri Susilo $^{(1)}$, Ribut Purwaningrum ${ }^{(2)}$, Rian Rokhmad Hidayat ${ }^{(3)}$ \\ Program Studi Bimbingan dan Konseling \\ Universitas Sebelas Maret Surakarta \\ E-mail: ats@staff.uns.ac.id
}

\begin{abstract}
Abstrak
Rasionalisasi pemilihan subjek berdasarkan hasil analisis kebutuhan bahwa Guru Bimbingan dan Konseling merasa kurang memiliki kompetensi dalam menyelesaikan permasalahan peserta didik kaitannya dengan peristiwa yang menyebabkan krisis dan trauma yang mendalam. Sehingga mereka menjadi kurang percaya diri dan terkesan kurang memiliki respectful mind saat menjumpai permasalahan tersebut. Kegiatan pelatihan ini diberikan kepada guru BK SMP dan SMA. Guru BK SMP dan SMA yang dipilih adalah sampel guru di kota Surakarta yaitu 15 orang Guru SMP dan 15 orang Guru SMA. Subjek tersebut diwadahi dalam kelompok Musyawarah Guru Bimbingan dan Konseling (MGBK) dan Asosiasi Bimbingan dan Konseling Indonesia (ABKIN) Cabang Surakarta yang memiliki kantor sekretariat di SMP Negeri 4 Surakarta dan SMA Negeri 1 Surakarta. Instrumen proses dari pelaksanaan kegiatan menunjukkan antusiasme, semangat, ketertarikan serta kesungguhan para guru mengikuti kegiatan yang bagi mereka adalah hal baru yang selama ini belum pernah diimplementasikan di sekolah. Evaluasi hasil menunjukkan bahwa para guru mampu memahami, merancang dan melaksanakan teknik-teknik konseling traumatik dengan kategori baik.
\end{abstract}

Kata Kunci: konseling traumatic, experiental learning, konselor

\begin{abstract}
Rationalization of subject selection is based on the results of the needs analysis that the Guidance and Counseling Teacher feels lacks competence in solving students' problems related to events that cause deep crises and trauma. So they become less confident and seem to lack respectful mind when meeting these problems. This training activity is given to BK Middle and High School teachers. The selected BK Middle and High School teachers are a sample of teachers in the city of Surakarta, which are 15 Middle School Teachers and 15 High School Teachers. These subjects were included in the Guidance and Counseling Teachers' Consultative Group (MGBK) and the Surakarta Branch of the Indonesian Guidance and Counseling Association (ABKIN) which has a secretariat office in SMP Negeri 4 Surakarta and SMA Negeri 1 Surakarta. The process instrument of the implementation of the activity shows the enthusiasm, enthusiasm, interest and seriousness of the teachers to take part in activities which for them are new things that have never been implemented in schools. Evaluation of results shows that teachers are able to understand, design and implement traumatic counseling techniques in either category
\end{abstract}

Keywords: traumatic counseling, experiential learning, counselor

\section{Info Artikel}

Diterima September 2019, disetujui Oktober 2019, diterbitkan Desember 2019 


\section{PENDAHULUAN}

Menurut Nova (2009:110), terdahap lima fase dalam krisis dan traumatik yaitu: (1) pre-crisis, yaitu keasaan yang ada sebelum krisis muncul namun sudah ada benih krisis dan keraguan di dalam individu; (2) warning, yang merupakan tahap yang krusial dan perlu disadari dan segera dicari solusinya sebelum semakin buruk. Kebanyakan orang mengabaikan tahap ini dan menunjukan sikap kaget, rejection, dan pretending; (3) acute crisis, tahap ini ditunjukan setelah menimbulkan dampak buruk dan individu akan diuji kemampuan dirinya dari segala aspek maupun meminta bantuan untuk mencari solusinya; (4) clean up merupakan tahap dimana individu sudah mampu berdamai dengan masalanya dan mengambil hikmah agar tidak terulang; (5) post-crisis ditunjukan dengan keadaan individu sudah kembali bersemangat dan membuattujuan-tujuan baru.

Peristiwa traumatik muncul saat inividu dihadapkan dengan kematian actual, berada dalam keadaan terancam, cedera serius dari fisik maupun psikisnya. Itu juga dapat terjadi melihat kejadian pada lingkungan sekitarnya yang membuatnya takut, tidak berdaya, horror dan penyesalan, yang intense. Pada anak, rasa takut yang kuat menunjukkan sebagai indikasi kecemasan dan trauma. Contoh peristiwa traumatis dihadapi yaitu seputar keluarga, pertengkaran, tawanan perang, penculikan, kekerasan, kecelakaan, pola asuh, penyakit parah dan kehilangan anggota keluarga (Flanerry, 1999: 98). Flanneri juga menambahkan gejala yang akan ditunjukan karena trauma: "All of Inividual who are traumatized will create symptoms showing that may include intrusive recollections of the event, avoidance of situation triggerr a traumatic memory with a numbing of general responsiveness, and much arousal in psycologica area".

Dari segi klinis, Goleman (Hatta, 201: 32-35) menyebutkan penderita trauma menunjukan berubahnya litar limbic yang terpusat pada amigdala, yang mengandung katekolamin yang memiliki dua reaksi kimia: adrenalin dan noradrenalina yang berfungsi sebagai penggerak tubuh dalam menghadapi kecemasan maupun ketakutan. Sehingga Jadi penderita trauma memiliki reaksi yang sangat reaktif pada amigdala yang memproduksi katekolamin yang terlalu banyak sehingga memberi respons pada kejadian yang tidak berbahaya dan tidak masuk akal. Digambarkan lebih lanjut oleh Scott, \& Stredling (2001) dalam Hatta $(2016 ; 29)$

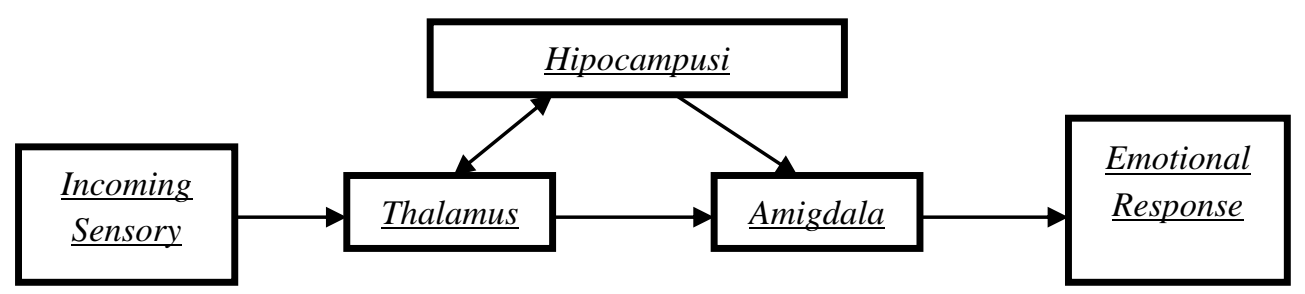

Gambar 1.

Skema proses terjadinya trauma secara klinis (Scott\& Streding, 2001)

Proses terjadinya trauma secara klinis dijelaskan dengan terjadi sesuatu yang ditangkap melalui indra pada tubuh (Incoming Sensory) yang masuk ke thalamus yang bertugas sebagai penafsir atau penerjemah terhadap informasi kemudian dikirimkan ke hipocampusi dan Amigdala secara bersamaan. Pada hippocampus merupakan bagian yang menyimpan memori jangka panjang amigdala. Amigdala bertanggung jawab terhadap respon yang harus dikeluarkan, selain itu amigdala juga bertanggung jawab terhadap perilaku untuk bertahan hidup individu dan melindungi diri sehingga terjadi 
gerakan rekfleks terhadap respon. Selain itu amigdala juga menyimpan respon terhadap memori tertentu sehingga individu akan bergerak otomatis terhadap rangsangan yang sama. Saat orang memiliki kriris dan trauma, hippocampusi tidak dapat berperasi dengan benar sehingga tidak dapat sehingga saat pemprosesan informasi kepada amigdala yang salah mengakibatkan amigdala memicu hormon adrenalin yang banyak terhadap peristiwa yang tidak mengancam sekalipun

Everly \& Mitchell (Flanerry, 1999: 78-79) beberapa gejala dari trauma:

Tabel 1.

Gejala Trauma Everly \& Mitchell (Flanerry, 1999: 78-79)

\begin{tabular}{|c|c|}
\hline \multirow{3}{*}{$\begin{array}{l}\text { Intrusive } \\
\text { Symptoms } \\
\text { (gejala yang } \\
\text { mengganggu) }\end{array}$} & $\begin{array}{l}\text { Mengalami peristiwa tersebut lagi dan terus menerus melalui } \\
\text { halusinasi, mimpi, lamunan dan lain - lain }\end{array}$ \\
\hline & $\begin{array}{l}\text { Paraoid karena berfikir peristiwa tersebut akan terulang dan kembali } \\
\text { lagi }\end{array}$ \\
\hline & $\begin{array}{l}\text { Secara simbolis dan fisik mengingat dan bereaksi mengenai } \\
\text { penderitaan atau kesusahan yang pernah dialami }\end{array}$ \\
\hline \multirow{5}{*}{$\begin{array}{l}\text { Avoidance } \\
\text { Symptoms } \\
\text { (Gejala } \\
\text { Penghindaran) }\end{array}$} & Menjauh dari tempat mauppun sesuatu yang meemicu trauma \\
\hline & Kesulitan mengingat peristiwa tentang trauma \\
\hline & Kehilangan minat mengenai kegiatan yang penting \\
\hline & Membatasi perasaabn dan ekpresi emosi \\
\hline & Putus asa dan berfikir tidak ada masa depan \\
\hline \multirow{5}{*}{$\begin{array}{l}\text { Arousal } \\
\text { Symptoms }\end{array}$} & Hyper-vigilance \\
\hline & $\begin{array}{l}\text { Respon menjerit karena ketakutan dengan berlebih dan tidak bisa } \\
\text { dikendalikan }\end{array}$ \\
\hline & $\begin{array}{l}\text { Insomnia, gangguan yang membuat individu kesulitan dalam } \\
\text { beristirahat }\end{array}$ \\
\hline & Gangguan konsentrasi \\
\hline & Tempremental, mudah marah dan sedih \\
\hline
\end{tabular}

James (Gladding, 2012: 289) Penanganan permasalahan krisis maupun traumatik mengenai apa yang harus dilakukan konselor dan kapan penanganan diberikan tergantung kepada hasil asesmen dan penelitian konselor itu sendiri. Sedangkan menurut Robert (2000: 86) penggunaan konseling krisis dan Critical Incident Stresse Debriefing (CISD) dapat dijadikan alternatif penanganan masalah krisis dan Traumatik. CISD merupakan pendekatan kelompok yang berorintasi tujuh tahap untuk membantu klien menghadapi perspektif, beliefs dan perasaan dalam suatu situasi terkontrol dengan melibatkan dua konselor. Sedangkan konseling krisis adalah konseling yang memanfaatkan berbagai pendekatan directive dan berorientasi tindakan, untuk membantu klien dalam menggali potensi menghadapi krisis secara eksteral (Gladding, 2012: 288). Dikutip dari Crisis Counseling Continuing Education Course (Aspira Continuing Education, 2010) menjelaskan konseling krisis didesign untuk menolong klien mengidentifikasi dan mengimplementasikan bermacam jenis konseling krisis serta mengevaluasi dan mengindentifikasi reaksi umum dari krisis dan gejalanya. Selain itu juga memanajemen stress dan menyadari dampaknya. Penggunaan bermacam pendekatan directive dan berfokus ke tindakan untuk membantu klien menyadari potensi diri untuk menghadapi krisis secara eksternal (Rahayu, 2017:53)

Romli (2012: 171) treatment yang dapat dilakukan untuk mereduksi atau mengentaskan permasalahan traumatik pada remaja dilakukan oleh konselor dengan beberapa strategi: Smile Child Center, Terapi bermain, terapi emosi dengan 
menggambar dan outbond. Terapi emosi dengan menggambar dan mewarnai dilaksanakan dengan tujuan agar anak-anak dapat menyalurkan pengalaman emosinya melalui media kertas dan alat tulis. Emosi atau perasaan memainkan peran.

Wainrib dan Block dalam Rohidj (2017: 95) mengembangkan model untuk menagani krisis dan traumatik yaitu General Crisis Response yang mengidentifikasi symptoms krisis secara keseluruhan klien yang terdapat tiga level yaitu: (1) level kognitif yaitu kemampuan menangani dan mekanisme coping yang tidak bisa ditangani; (2) level psikologis yaitu keadaan kaget yang bersifat semetara yang dilanjutkan dengan penolakan, kesedihan, ketakutan, penyangkalan, bingung, tidak percaya dan reaksi lain yang membuat individu tidak seimbang; (3) level fisiologis yaitu reaksi stres umum dari segi fisik.

Hidayat (2008: 133-134) Pendekatan Rational Emotive Therapy dapat digunakan dalam menangani permasalahan krisis dan traumatik salah satunya stategi bibliokonseling. Corey juga menjelaskan (Andersen, 2000: 21) menjelaskan "Some of the cognitive interventions ofREBT include disputation of irrational beliefs, cognitive homework, bibliotherapy, changing one's language, and use of humor". Konselor bertugas untuk menyadarkan klien dari irrational beliefs yang dianut dengan mengidentifikasi dan rasionalisasi keadaan yang sebenarnya. Pendekatan Cognitive Behavior Therapy (CBT) juga dapat digunakan dengan merekonstruksi pemikiran klien.

Konseling traumatik adalah upaya pemberian bantuan pada konseli dengan kondisi trauma. Konseling traumatik berupa upaya yang bersifat kuratif dan pengembangan. Berdasarkan kajian, kondisi traumatik bervariasi bergantung pada penyebab trauma itu sendiri. Levers menjelaskan kondisi traumatik bisa berupa: a) trauma pada anak-anak (usia 8-12 tahun), b) trauma pada remaja, c) trauma seksual, d) trauma adiksi dan psikologis, e) trauma korban kekerasan/ kriminal, f) trauma pembunuhan dan bunuh diri, g) trauma intoleransi etnis, h) trauma prejudis dan ketidakadilan seksual dan gender, i) trauma bullying sekolah, dan j) trauma bencana alam.

Ditilik dari kondisi traumatik yang ada di sekolah, berbagai kondisi traumatik banyak ditemui di lapangan. Hal ini menjadi perhatian khusus bagi para guru BK mengingat karakteristik kondisi traumatik bagi masing-masing konseli berbeda. Kondisi traumatik juga tidak bisa disamakan dengan kondisi non-traumatik sehingga proses pemberian bantuan-pun tidak bisa disamakan. Berdasarkan hasil analisis kebutuhan bahwa Guru Bimbingan dan Konseling merasa kurang memiliki kompetensi dalam konseling, khususnya menyelesaikan permasalahan peserta didik kaitannya dengan peristiwa yang menyebabkan krisis dan trauma yang mendalam. Sehingga mereka menjadi kurang percaya diri dan terkesan kurang memiliki respectful mind saat menjumpai permasalahan tersebut. Padahal berhasil atau gagalnya peserta didik dalam melewati krisis dan trauma psikologis memberi pengaruh pada tahap kehidupan selanjutnya.

Hal yang kemudian menjadi masalah adalah bahwa para guru BK di lapangan belum banyak yang mengenal konseling traumatik secara khusus. Hal ini menyebabkan guru BK kurang memahami bagaimana mempraktikkan konseling traumatik dengan baik di lapangan. Pelatihan konseling traumatik dibutuhkan untuk memberikan keterampilan konseling traumatik pada guru BK. Adapun metode paling tepat adalah menggunakan model pelatihan experiential learning.

Model experiential learning dari Kolb (1984) merupakan model pelatihan yang berbasis rekonstruksi pengalaman. Model experiential learning memiliki empat tahapan, 
yaitu (1) pengalaman konkrit, (2) observasi reflektif, (3) konseptualisasi abstrak, dan (4) eksperimentasi aktif, yang bisa dilakukan dengan berbagai pilihan aktivitas. Aktivitas pelatihan yang dapat dilakukan misalnya diskusi dan dialog, simulasi, permainan peran, biblio-learning, dan penayangan film (Kolb dan Kolb, 2004). Experiential learning merupakan model pelatihan yang mengkombinasikan bagaimana seseorang menyerap dan merekonstruksi pengalaman sebagai dasar untuk belajar (Kolb, 2009).

Model pelatihan experiential learning dipilih sebagai strategi untuk pelatihan konseling traumatik merujuk pada penelitian McAuliffe (2002), yang menyatakan bahwa hampir semua pendidikan para profesional termasuk konselor, memerlukan model pelatihan yang berbasis pengalaman sebagai dasar dalam pelatihan. Dengan menggunakan experiential learning, maka konselor akan memperoleh keuntungan, yaitu: (1) mendapatkan pengalaman di sini dan saat ini (here and now experience) lebih baik jika dibandingkan dengan hanya membaca atau memahami konsep, dan (2) adanya refleksi dari setiap pemberian pengalaman belajar pada konselor, memungkinkan untuk menjadikan hal tersebut sebagai dasar bagi penarikan kesimpulan atas proses pelatihan, sehingga akan berdampak positif pada pelatihan selanjutnya.

Diperkuat lagi oleh penelitian Freitas, et. al. (2010), experiential learning perlu untuk dilakukan sebagai salah satu bentuk inovasi pelatihan. Pelatihan tradisional yang menitikberatkan pada komunikasi searah oleh pengajar dinilai tidak maksimal dalam memberikan kesempatan pada mahasiswa untuk memperoleh pengalaman belajar. Pelatihan tradisional hanya berputar-putar pada pola transfer pengetahuan dan dilakukan hanya berdasarkan pada teks yang ada, sehingga seakan-akan pihak yang dilatih tidak memiliki kesempatan untuk meningkatkan keterampilan-keterampilan yang lain selain belajar dari buku dan penjelasan pelatih. Melalui experiential learning pelatihan dapat dimodifikasi menjadi lebih menarik dan bervariasi, sehingga berimplikasi pada meningkatnya hasil belajar dan keterampilan siswa.

\section{METODE PENELITIAN}

\section{Metode Pelatihan Experiential Learning}

Salah satu model pelatihan yang berkembang adalah model experiential learning (pelatihan melalui pengalaman). Model pelatihan ini bertujuan untuk mengembangkan pemahaman dan capaian hasil belajar lainnya melalui pengalaman (experience) (Kolb, 1984). Pengalaman diposisikan sebagai proses belajar sekaligus sumber belajar. Model ini mulai berkembang sejak awal abad ke 20 dengan fokus utamanya adalah menempatkan pengalaman sebagai proses dan sumber belajar.

\section{Subjek Pelatihan}

Pelatihan dilakukan dengan subjek konselor yang berasal dari perwakilan anggota musyawarah guru bimbingan dan konseling (MGBK) sekaligus anggota asosiasi bimbingan dan konseling indonesia cabang Surakarta (ABKIN Surakarta) berjumlah 30 orang yang terbagi ke dalam tiga kelompok besar. Masing-masing kelompok akan mengimplementasikan model pelatihan experiential learning. Kegiatan pelatihan ini diberikan kepada guru BK SMP dan SMA. Guru BK SMP dan SMA yang dipilih adalah sampel guru di kota Surakarta yaitu 15 orang Guru SMP dan 15 orang Guru SMA. Subjek tersebut diwadahi dalam kelompok Musyawarah Guru Bimbingan dan Konseling (MGBK) dan Asosiasi Bimbingan dan Konseling Indonesia (ABKIN) Cabang Surakarta yang memiliki kantor sekretariat di SMP Negeri 4 Surakarta dan SMA Negeri 1 Surakarta. 
Experiential learning merupakan sebuah teori holistik yang mendefinisikan belajar sebagai sebuah proses utama dari adaptasi manusia dalam keterlibatannya secara utuh. Sebagai contoh, pelatihan melalui pengalaman (experiential learning) dapat diaplikasikan tidak saja dalam kelas pendidikan formal, namun juga dalam semua bidang kehidupan. Proses belajar melalui pengalaman bersifat fleksibel dalam hal tempat dan waktu, selalu hadir dalam setiap aktivitas di manapun dan kapanpun.

Hakekat holistic dari proses pelatihan berarti proses tersebut dapat terjadi pada berbagai kalangan mulai dari individu hingga kelompok, organisasi dan masyarakat secara menyeluruh. Kajian penelitian mengenai model pelatihan ini telah dilaksanakan di seluruh dunia untuk mendukung kebergunaan teori ini secara lintas budaya. Sehingga tidak mengejutkan apabila penelitian mengenai experiential learning ditemui secara interdisipliner dan menyeluruh ke berbagai bidang ilmu.

\section{PEMBAHASAN}

Model pelatihan experiential learning bertujuan mengintegrasikan teori dan praktik pelatihan agar pebelajar memperoleh hasil belajar yang utuh. Terdapat sejumlah aktivitas pelatihan melalui pengalaman yang dapat mengaktifkan pebelajar membangun sikap dan nilai-nilai, pengetahuan dan keterampilannya melalui pengalaman nyata. Pebelajar dilatih untuk memandang kritis kegiatan tersebut melalui proses refleksi. Kemudian, mereka memperoleh pemahaman dan dituangkan dalam bentuk lisan atau tulisan sesuai dengan tujuan pelatihan. Pengalaman digunakan untuk membantu pebelajar mengembangkan kapasitas dan kemampuannya. Dalam penerapan model experiential learning, pendidik dituntut untuk merancang aktivitas belajar yang akan dihadirkan dan diterjadikan pada peserta didik. Aktivitas pelatihan berfokus pada peserta didik (student-centered-learning), sehingga harus dipersiapkan sejumlah rancangan aktivitas sebagai pemandu pelatihan peserta didik.

Experiential learning mengartikan belajar sebagai proses di mana pengetahuan diciptakan melalui pengelolaan pengalaman. Pengetahuan merupakan hasil dari penyerapan dan pengelolaan pengalaman. Model pelatihan experiential learning menggambarkan dua model dialektis yang saling berhubungan dalam penyerapan pengalaman, yaitu pengalaman konkrit (concrete experience/ CE) dan konseptualisasi abstrak (abstract conceptualization/ AC), serta dua model dialektis yang saling berhubungan dalam pengelolaan pengalaman, yaitu observasi reflektif (reflective observation/ RO) dan eksperimentasi aktif (active experimentation/ AE) (Kolb, 1984). Dikatakan sebagai model dialektis, sebab keduanya merupakan proses pelatihan yang sama sekali berbeda antara yang satu dengan lainnya, namun apabila penggunaannya digabungkan dalam satu model pelatihan tertentu, dalam hal ini adalah experiential learning, maka akan diperoleh hasil yang sangat besar.

Experiential learning merupakan proses konstruksi pengetahuan yang melibatkan keempat model pelatihan sebagaimana tersebut di atas. Proses ini digambarkan oleh siklus atau spiral belajar di mana peserta didik sebagai pebelajar memiliki kesempatan untuk "menyentuh segala aspek" yang ada di dalamnya, yaitu mengalami, merefleksi, berpikir, dan bertingkah laku (experiencing, reflecting, thinking, and acting) dalam proses yang berulang sebagai bentuk responsif dari situasi belajar yang ada serta materi pelatihan yang disajikan (Kolb, 1984). 


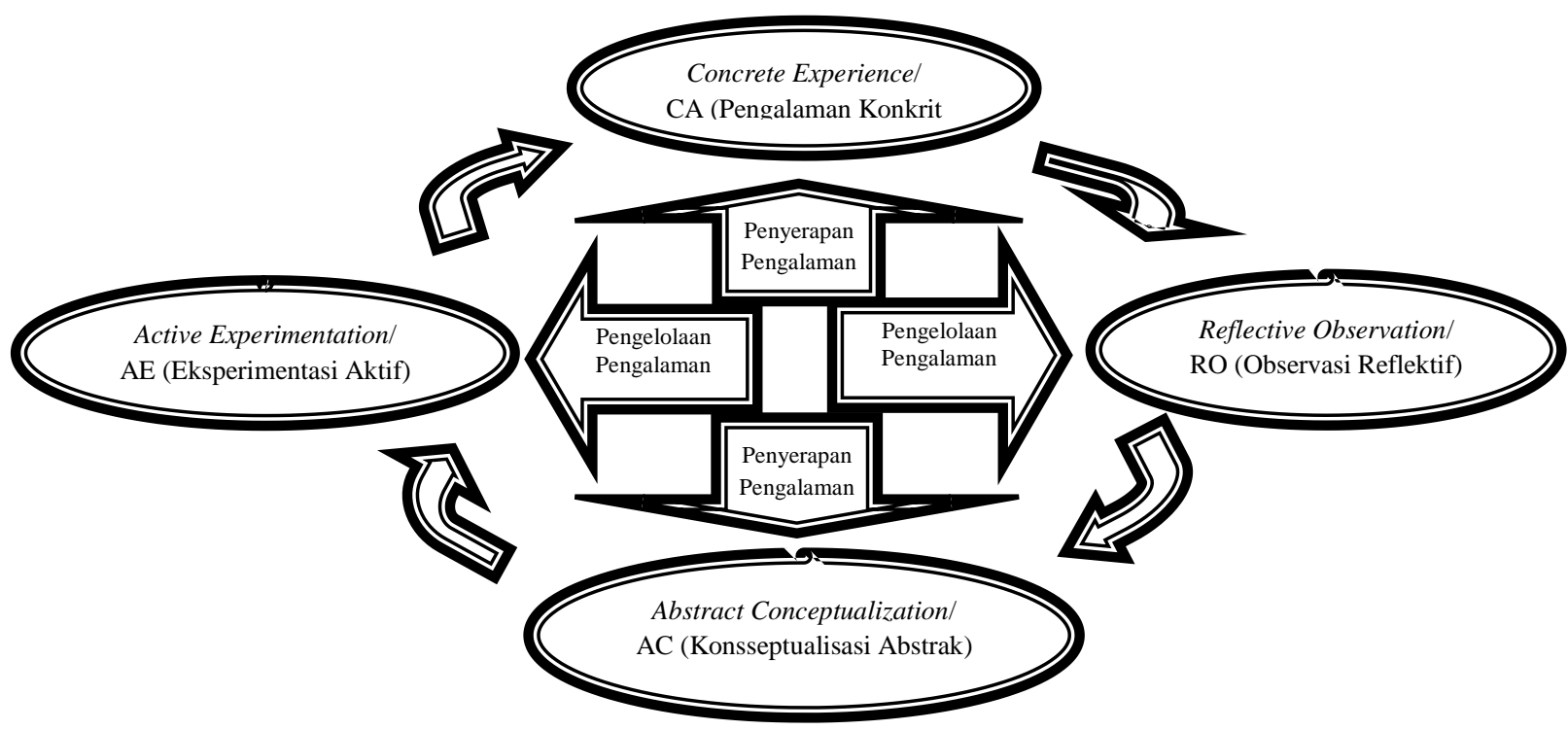

Gambar 2.

Siklus Experiential Learning (Kolb, 1984)

Adapun penjabaran dari langkah-langkah tersebut adalah sebagai berikut:

1. Concrete experience (feeling): Munculnya situasi tertentu sehingga menimbulkan proses belajar melalui pengalaman yang bersifat spesifik, yang bermuara pada timbulnya kepekaan terhadap situasi yang ada. Pada tahap ini pelatih menyediakan stimulus yang mendorong anggota pelatihan melakukan sebuah aktivitas. Aktivitas ini bisa berangkat dari suatu pengalaman yang pernah dialami sebelumnya baik formal maupun informal atau situasi yang realistik. Aktivitas yang disediakan bisa di dalam ataupun di luar kelas dan dikerjakan oleh pribadi atau kelompok.

2. Reflective observation (observing): Mengamati lingkungan dari perspektifperspektif yang berbeda, mengamati proses belajar yang berujung pada pembentukan makna. Pada tahap ini anggota pelatihan mengamati pengalaman dari aktivitas 'yang dilakukan. Selanjutnya anggota pelatihan merefleksikan pengalamannya dan dari hasil refleksi ini mereka menarik pelajaran. Dalam hal ini proses refleksi akan terjadi bila pelatih mampu mendorong peserta didik untuk mendeskripsikan kembali pengalaman yang diperolehnya, mengkomunikasikan kembali dan belajar dari pengalaman tersebut.

3. Abstract conceptualization (thinking): Merumuskan apa yang diperoleh dari situasi tertentu ke dalam konsep abstrak tertentu. Setelah melakukan observasi dan refleksi, maka pada tahap pembentukan konsep abstrak anggota pelatihan mulai mencari alasan, hubungan timbal balik dari pengalaman yang diperolehnya. Selanjutnya pembelajar mulai mengkonseptualisasi suatu teori atau model dari pengalaman yang diperoleh dan mengintegrasikan dengan pengalaman sebelumnya. Pada fase ini dapat ditentukan apakah terjadi pemahaman baru atau proses belajar pada diri anggota pelatihan atau tidak. Jika terjadi proses belajar, maka: (a) anggota pelatihan akan mampu mengungkapkan aturan-aturan umum untuk mendeskripsikan pengalaman tersebut, (b) anggota pelatihan menggunakan teori yang ada untuk menarik simpulan terhadap pengalaman yang diperoleh, dan (c) anggota pelatihan mampu menerapkan teori yang terabstraksi untuk menjelaskan pengalaman tersebut. 
4. Active experimentation (doing): Merencanakan apa yang akan dilakukan pada tahap selanjutnya sesuai dengan konsep abstrak yang telah ada dalam kepala. Di sini terjadi proses transfer of learning di mana pengalaman yang diperoleh pada saat ini dapat diaplikasikan dalam proses belajar selanjutnya.

Pengalaman konkrit merupakan dasar bagi individu untuk melakukan observasi dan refleksi. Refleksi disusun untuk dipahami dan disaring ke dalam konsep abstrak yang mana tingkah laku baru dapat digambarkan. Implikasi ini dapat diuji dan disajikan sebagai acuan untuk menciptakan pengalaman baru.

Berhubungan dengan siklus yang tergambar di atas, dapat disimpulkan bahwa proses pembelajaran peserta didik tidak hanya diterjadikan dalam salah satu tahap saja. Meskipun pengalaman merupakan dasar dari model belajar yang lain, namun bukan berarti hanya tahap pengalaman konkret/ CE yang 'dialami' oleh peserta didik. Semua model belajar yang terdapat dalam siklus experiential learning diterjadikan dan dialami oleh peserta didik. Model penyerapan pengalaman, yaitu model pengalaman konkrit dan konseptualisasi abstrak, serta model transformasi pengalaman, yaitu model observasi reflektif dan eksperimentasi aktif, keempatnya merupakan bagian yang harus ada dan dialami oleh peserta didik dalam keseluruhan siklus experiential learning.

Experiential learning mempunyai enam karakteristik utama, yaitu: (1) belajar terbaik dipahami sebagai suatu proses. Tidak saja dalam kaitannya dengan hasil yang dicapai, (2) belajar adalah suatu proses berkelanjutan yang didasarkan pada pengalaman, (3) belajar memerlukan resolusi konflik-konflik antara model-model belajar dengan cara dialektis, (4) belajar adalah suatu proses yang holistik, (5) belajar melibatkan hubungan antara seseorang dan lingkungan, dan (6) belajar adalah proses tentang menciptakan pengetahuan yang merupakan hasil dari hubungan antara pengetahuan sosial dan pengetahuan pribadi (Kolb, 1984).

Experiential learning adalah suatu pendekatan yang dipusatkan pada peserta didik, yang dimulai dengan landasan pemikiran bahwa cara belajar paling baik adalah dari pengalaman. Untuk bisa memperoleh pengalaman belajar yang efektif, harus menggunakan siklus belajar yang komprehensif, dari pengaturan tujuan, melakukan observasi dan eksperimen, memeriksa ulang, dan merencanakan tindakan. Jika keseluruhan proses dalam siklus ini sudah terjadi pada peserta didik, maka hal ini memungkinkan mereka untuk belajar keterampilan baru, sikap baru atau bahkan cara berpikir baru (Kolb, 1984).

Di dalam proses pelatihan dengan metode experiental learning, pelatih berperan sebagai fasilitator. Hal ini dapat diartikan bahwa pelatihan hanya memberikan bimbingan (guide), tidak memberikan informasi secara sepihak dan menjadi sumber pengetahuan tunggal. Setelah peserta didik melakukan aktivitas yang telah dirancang sebelumnya, hal yang selanjutnya dilakukan adalah mengabstraksikan sendiri pengalamannya. Sebagai contoh, anggota pelatihan mengeksplorasi perasaan apa yang mereka alami setelah mendapatkan penjelasan, contoh, dan latihan dari pelatihan, permasalahan apa yang muncul dalam pikiran mereka dengan pembelajaran seperti yang disajikan, kemungkinan-kemungkinan seperti apa yang mungkin bisa dijadikan alternatif untuk penyelesaian permasalahan yang muncul, serta apa keterampilan apa yang mungkin dikembangkan untuk meningkatkan dan memperbaiki diri di masa yang akan datang.

Sehingga, kompetensi yang harus dimiliki oleh pelatih untuk berperan sebagai fasilitator adalah menciptakan suasana belajar yang menyenangkan sehingga memungkinkan anggota pelatihan untuk terlibat aktif dalam pembelajaran, menyiapkan 
instrumen observasi dan mengobservasi perilaku peserta didik, menumbuhkan sikap netral dan kepercayaan pada peserta didik atas kemampuan mereka untuk menilai sendiri proses belajar mereka, serta untuk memecahkan permasalahan yang muncul dalam kegiatan belajar pada khususnya.Jika disintesakan secara sederhana, pada dasarnya pembelajaran model pembelajaran experiential learning dimulai dengan melakukan (do), mengamati (observe), merefleksikan (reflect) dan menerapkan (apply). Begitu seterusnya kembali ke fase pertama secara terus menerus dan tidak pernah berhenti.

Jika disintesakan secara sederhana, pada dasarnya pelatihanmodel pembelajaran experiential learning dimulai dengan melakukan (do), mengamati (observe), merefleksikan (reflect) dan menerapkan (apply). Begitu seterusnya kembali ke fase pertama secara terus menerus dan tidak pernah berhenti.

Guru-guru BK diminta untuk melakukan simulasi sebagai wujud experiential learning dari materi yang telah diberikan. Berdasarkan instrumen proses dari pelaksanaan kegiatan menunjukkan antusiasme, semangat, ketertarikan serta kesungguhan para guru mengikuti kegiatan yang bagi mereka adalah hal baru yang selama ini belum pernah diimplementasikan di sekolah. Kemudian melalui evaluasi hasil menunjukkan bahwa para guru mampu memahami, merancang dan melaksanakan teknik-teknik konseling traumatik dengan kategori baik.

\section{SIMPULAN DAN REKOMENDASI}

Kondisi traumatik tidak hanya terjadi pada siswa di eks-Karesidenan Surakarta. Banyak kondisi traumatik dapat dijumpai di seluruh wilayah di Indonesia. Pelatihanpelatihan serupa direkomendasikan dilakukan hingga ke seluruh Indonesia sehingga sebagian besar konselor di Indonesia mengenal dan teredukasi bagaimana memberikan konseling traumatik yang bisa mengentaskan masalah-masalah traumatik pada siswa. Keterampilan ini mendukung posisi konselor sebagai professional helper di lingkungan pendidikan formal. Merujuk pada kondisi traumatik yang semakin waktu semakin meningkat, menunjukkan bahwa eksistensi konselor di sekolah untuk menangani kondisi ini semakin dibutuhkan.

\section{DAFTAR PUSTAKA}

Flanerry, R. 1999. Psychological Trauma and Post Traumatic Stress Disorder. 1(1), 77 83. Harvard Medical School

Freitas, et. al. 2009. Learning as immersive experiences: Using the four-dimensional framework for designing and evaluating immersive learning experiences in a virtual world. British Journal of Educational Technology 2010 Vol. 41 No. 01.

Gladding. 2012. Konseling: Profesi yang menyeluruh. Jakarta: Permata Puri Media.

Hata, K. 2014. Trauma dalam Kalangan Remaja SMP mangsa konflik bersenjata dan Tsunami di Aceh. Universitas Malaysia

Hatta, K. 2016. Trauma dan Pemilihannya: Suatu kajian berdasarkan kasus pasca konflik dan tsunami. Banda Aceh (Indonesia): Dakwah Ar-Raniry Press 
Hidayat, M. Y 2008. Aplikasi Bibliokonseling .11(1), 129 - 140. Universitas Pendidikan Indonesia

Kolb, D. A. 1984. Experiential Learning : Experiences as The Source of Learning and Development. Englewood Cliffts, New Jersey: Prentince Hall Inc.

Kolb, D. A. \& Kolb, A. Y. The Learning Way : Meta-cognitive Aspects of Experiential Learning. Simulation and Gaming Journal 2009, 40 : 297.

Lawrence, I \& Silverberg DO. 2003. Special Communication, 103(3) 131- 135

McAuliffe. Student Changes, Program Influences, and Adult Development in One Program of Counselor Training: An Exploratory Inductive Inquiry. Journal of Adult Development, Vol. 9, No. 3, July 2002.

Nova, F. 2009. Crisis Public Relations: Bagaimana Menangani Krisis Perusahaan. Jakarta: Kompas Gramedia

Rahayu, S. M., 2017. Konseling Krisis: Sebuah Pendekatan dalam Mereduksi Masalah Traumatik pada Anak dan Remaja. 2 (1), 53-56. Universitas Mulawarman

Romli, M. E. 2012. Upaya konselor untuk mengatasi trauma di kalangan mahasiswa. .International Seminar \& Workshop Post Traumatic Counseling, STAIN Batusangkar

Swart. I., 2005. Post Stress and Traumatic Disorder, 1(1),47-103 Universiteit Van Pretoria 